\title{
Groundwater Quality beneath an Asian Megacity on a Delta: Kolkata's (Calcutta's) Disappearing Arsenic and Present Manganese
}

\author{
J. M. McArthur, ${ }^{* \dagger}$ P. K. Sikdar, ${ }^{\ddagger}$ M. J. Leng, ${ }^{\S, \|}$ U. Ghosal, ${ }^{\ddagger}$ and I. Sen ${ }^{\ddagger}$ \\ ${ }^{\dagger}$ Earth Sciences, University College London, Gower Street, London WC1E 6BT, United Kingdom \\ ${ }^{*}$ Department of Environment Management, Indian Institute of Social Welfare and Business Management, Management House, \\ College Square (West), Kolkata 700 073, India \\ ${ }^{\S}$ NERC Isotope Geosciences Laboratory, British Geological Survey, Keyworth, Nottingham NG12 5GG, United Kingdom \\ "Centre for Environmental Geochemistry, School of Biosciences, Sutton Bonington Campus, University of Nottingham, \\ Loughborough LE12 5RD, United Kingdom
}

\section{Supporting Information}

ABSTRACT: Kolkata, the capital city of West Bengal, exploits groundwater for public water-supply. The groundwater has been reported to be widely polluted by arsenic (As). Analysis for As in 280 groundwaters from across Kolkata, failed to detect As concentrations $>10 \mu \mathrm{g} / \mathrm{L}$ from natural processes. Arsenic concentrations between 10 and $79 \mu \mathrm{g} / \mathrm{L}$ found in 14 of the 280 groundwaters are remnant from a pollution-plume emanating from a single factory site where Paris Green, an arsenical pesticide, was manufactured between 1965 and 1985. In 45\% of groundwaters sampled, concentrations of $\mathrm{Mn}$ exceed $0.4 \mathrm{mg} / \mathrm{L}$, a putative health guideline value for drinking water. Sporadic minor hazards are posed by $\mathrm{Pb}>10 \mu \mathrm{g} / \mathrm{L}$ introduced into groundwater from well-fittings, from $4 \%$ of groundwaters with $\mathrm{F}$ concentrations between 0.75 and $1 \mathrm{mg} / \mathrm{L}$, and the $14 \%$ of groundwaters containing more than $500 \mathrm{mg} / \mathrm{L} \mathrm{Na}$, concentrations that might contribute to

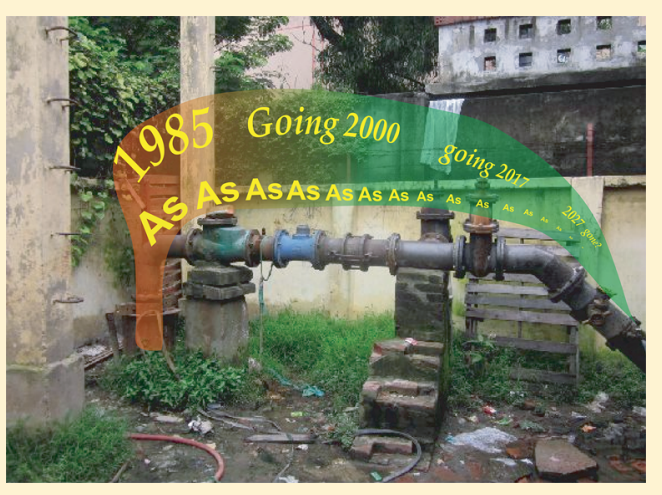
excessive daily intake of $\mathrm{Na}$. Compounding hazards from $\mathrm{As}, \mathrm{F}, \mathrm{Mn}, \mathrm{Na}$, and $\mathrm{Pb}$, shows that $64 \%$ of public wells and $40 \%$ of municipal wells supply groundwater of suspect quality. Groundwaters comply with WHO Guideline Values for drinking water in terms of $\mathrm{Cr}, \mathrm{Cu}, \mathrm{Co}, \mathrm{NO}_{2}, \mathrm{NO}_{3}, \mathrm{Sb}$, Se, and $\mathrm{U}$. Aesthetic guideline values for $\mathrm{Fe}, \mathrm{Mn}, \mathrm{SO}_{4}$, and $\mathrm{Cl}$ are exceeded for many groundwaters.

\section{INTRODUCTION}

Urban developments on deltas commonly exploit groundwater for water-supply. Increasing abstraction is driven by increasing populations, and by increasing pollution of surface water that makes alternative sources necessary. ${ }^{1-4}$ The increasing demand for groundwater leads to over-abstraction, a decline in groundwater levels and well-yields, deteriorating water quality, and land subsidence. ${ }^{4-7}$

An additional hazard in and around some Asian cities is the

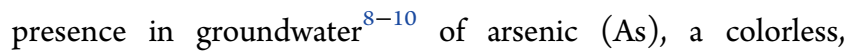
odorless, tasteless carcinogen. Kolkata, known as Calcutta before 2001, is such a city. The shallow aquifers around Kolkata are known to be widely polluted by $\mathrm{As}^{11-14}$ and widespread pollution by As of groundwater beneath the city itself has also been reported. ${ }^{15-17}$ Kolkata, however, taps only a late Pleistocene aquifer of brown over gray sands. This aquifer, commonly termed "the deep aquifer", occurs across the Bengal Basin and is reported elsewhere to yield low-As groundwater. ${ }^{18-20}$ In contrast, groundwater in the overlying, mostly Holocene, "shallow" aquifer is commonly As-polluted across the Bengal Basin., 98,19
Presented with claims that groundwater in the late Pleistocene aquifer under Kolkata is polluted by As, while groundwater in the late Pleistocene aquifer elsewhere in the Bengal Basin is not, we surveyed As concentrations in groundwater beneath Kolkata in order to resolve the apparent conflict. The data we collected allow us also to use $\mathrm{Cl} / \mathrm{Br}$ to assess the degree to which surface pollution is being drawn into the aquifer by abstraction for municipal water supply, and to comment on other potential chemical hazards in groundwater.

We restricted our study to the $205 \mathrm{~km}^{2}$ of Kolkata lying within the administrative area of the Kolkata Municipal Corporation (KMC, Figure 1) because those reporting Aspollution beneath Kolkata did so. ${ }^{15-17}$ Between September, 2015 and February, 2017, we sampled 206 public hand-pumped wells, 4 motor-pumped private wells, and 70 electrically pumped municipal supply wells (Figures 1, 2, and S1 of the Supporting Information, SI). Public wells are low-discharge,

Received: September 27, 2017

Revised: April 4, 2018

Accepted: April 6, 2018 


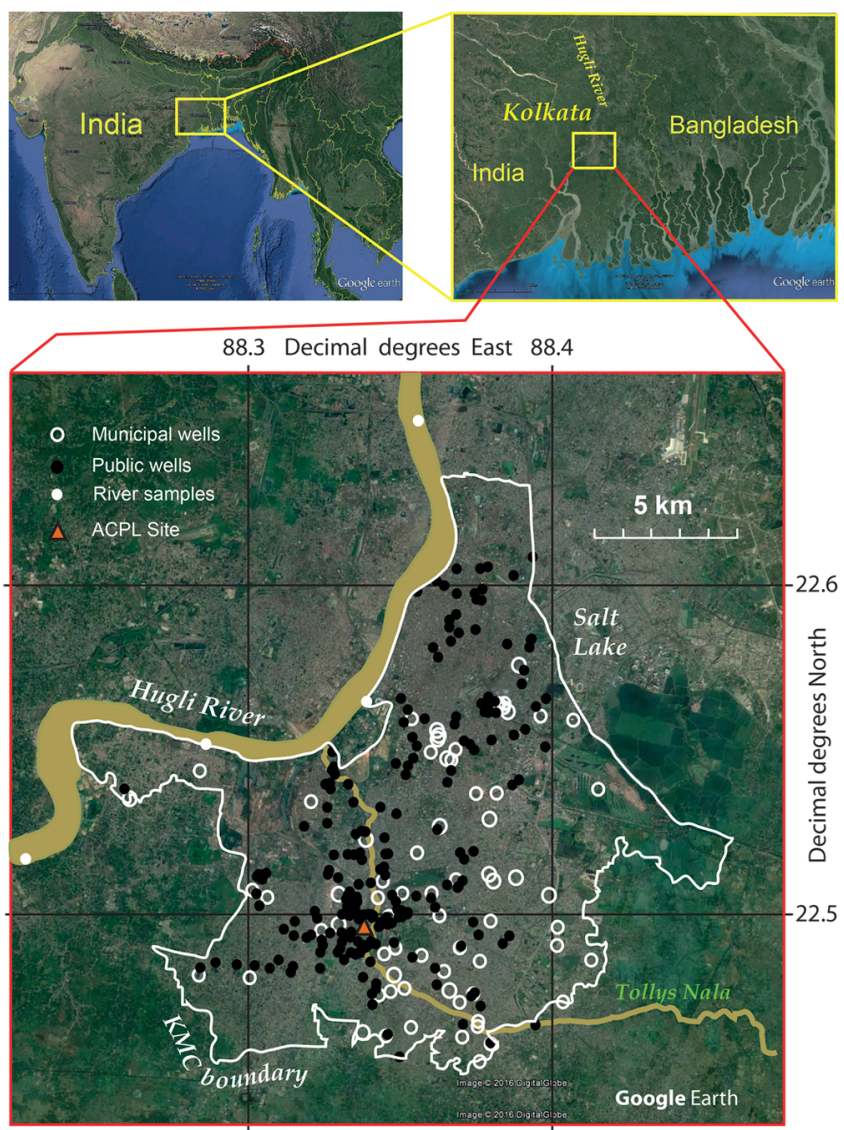

Figure 1. Map showing the boundary of the Kolkata Municipal Corporation (KMC) and the locations of sampled wells, 4 of 5 riversampling sites (the fifth is $13 \mathrm{~km}$ north of the map limit) and the location of the ACPL factory (red filled triangle at $88.339^{\circ} \mathrm{E}, 22.496^{\circ}$ N) that manufactured Paris green, an arsenical pesticide, between 1965 and 1985. GPS of all locations are in Table S1 to WGS84, as used in Google Earth.

hand-pumped, and installed for public use in public places, e.g., along roadsides and in parks (Figure S1): sampled wells have a median depth of $91 \mathrm{~m}$ and are fitted with screens $6 \mathrm{~m}$ in length sited at the bottom of the well. Municipal wells are highcapacity wells fitted with submersible electric pumps that feed municipal supply via a piped-water distribution system (Figure S1): sampled wells have a median depth to base of the hole of $121 \mathrm{~m}$ and are fitted with screens $20 \mathrm{~m}$ in length sited at the base of the well (Table S1 of the SI). We also sampled the Hugli River at 5 sites (Figure 1) that were distributed upstream, centrally, and downstream, of KMC, and did so on four occasions: October, 2015 and January, April, and July, 2016. Data are in the SI (Table S1), with our methodology.

\section{KOLKATA'S WATER SUPPLY}

Kolkata lies on the east bank of the Hugli River at an altitude between 6 and $9 \mathrm{~m}$ above mean sea level. It is home to some 13 million inhabitants of whom 4.6 million live within administrative area of the $\mathrm{KMC}{ }^{21}$ which is the historical core of the city (Figure 1; https://www.kmcgov.in/KMCPortal/jsp/ KolkataStatistics.jsp). Groundwater provides $25 \%$ of the city's water supply and is drawn by private motorized wells operated by industry, housing estates, and high-rise apartments. ${ }^{22}$ Another $10 \%$ is groundwater drawn from $\sim 260$ electrically pumped municipal wells that are typically 100 to $150 \mathrm{~m}^{\text {deep }}{ }^{23}$
(Figure 2). Some 10000 public hand-pumped shallow wells are also estimated to exist in the KMC. ${ }^{24}$ The volume abstracted by public wells is insignificant compared to that abstracted by motorized municipal and private wells but their importance to public supply of water is great.

Decades of high-capacity pumping of groundwater has lowered the groundwater level in parts of the city by up to $14 \mathrm{~m}$, creating cones-of-depression in the east, west and north of KMC (Figure 3). The groundwater high between the eastern and western depressions arises because recharge is occurring from Tolly's Nala.

\section{GEOLOGICAL AND HYDROLOGICAL SETTING}

3.1. Aquifers of the Bengal Basin. The subsurface sediments of the upper few hundred meters of the southern Bengal Basin, including southern West Bengal, comprise a buried late Pleistocene landscape of palaeo-channels and palaeo-interfluves overlain by younger fluvial sediments. The late Pleistocene landscape formed between 125 and $18 \mathrm{ka}$ when sea-level declined and the sea retreated southwards from the basin. ${ }^{25}$ On the interfluves, weathering created a lateritic clay soil $^{26,27}$ here termed the last glacial maximum palaeosol ${ }^{28,29}$ (LGMP). As sea-level rose to around its present level in the interval 18 to $6 \mathrm{ka}$ and transgressed across this landscape, ${ }^{26,27,29-33}$ it was buried beneath mostly Holocene alluvial sediments infilling the accommodation space created (Figure 4).

This geological development created two major aquifer systems across the Bengal Basin. Above the LGM surface, younger palaeo-channels infilled with gray sands form "shallow" aquifers. Here we use the term "Holocene". Pollution of groundwater by arsenic is widespread in these aquifers. ${ }^{9,12,18,19,33-35}$ Downward from the base of the LGMP and of indeterminate depth (i.e., typically more than several hundred meters) there is a "deep aquifer" of brown sands over gray sands, hereinafter termed the late Pleistocene aquifer. The late Pleistocene aquifers contain groundwater that has $<10$ $\mu \mathrm{g} / \mathrm{L}$ of naturally derived As, ${ }^{18-20}$ with trivial exceptions. ${ }^{36,37}$

Groundwaters in the late Pleistocene aquifers are low in As $(<10 \mu \mathrm{g} / \mathrm{L})$ because As, held by reversible sorption to mineral surfaces, notable Fe-oxyhydroxides, was flushed from the aquifers during the period $125 \mathrm{ka}$ to $18 \mathrm{ka}^{18}$ when groundwater flow-through was strong as sea-level fell from around its present level at $125 \mathrm{ka}$ to $120 \mathrm{~m}$ below the present level at the LGM at $18 \mathrm{ka}$.

The late Pleistocene and Holocene aquifers are separated by the LGMP, except in those late Pleistocene palaeo-channels where it was never formed (e.g., the Adi Ganga deep palaeochannel in Kolkata) because they contained active rivers, or where Holocene river incision has removed it. The LGMP is an effectively impermeable barrier to flow between the two aquifer systems.

3.2. Aquifer beneath Kolkata. The lithology of the sediments beneath the KMC is shown in Figure 5 as a fence diagram based on cores $^{26}$ and lithological logs from 109 rotarydrilled boreholes. ${ }^{38,39}$ In summary, an aquifer comprising $\sim 280$ $\mathrm{m}$ of late Pleistocene sands lies between a lower aquiclude of thick clay and an upper aquitard of the LGMP and overlying floodplain silts, clays and peats. In detail, at depths between 320 and at least $600 \mathrm{mbgl}$ lies a clay of indeterminate age with occasional intercalations of sand. This basal clay is overlain by a late Pleistocene sand aquifer containing laterally impersistent clay interbeds. The sand is gray beneath $60 \pm 20 \mathrm{~m}$ depth 


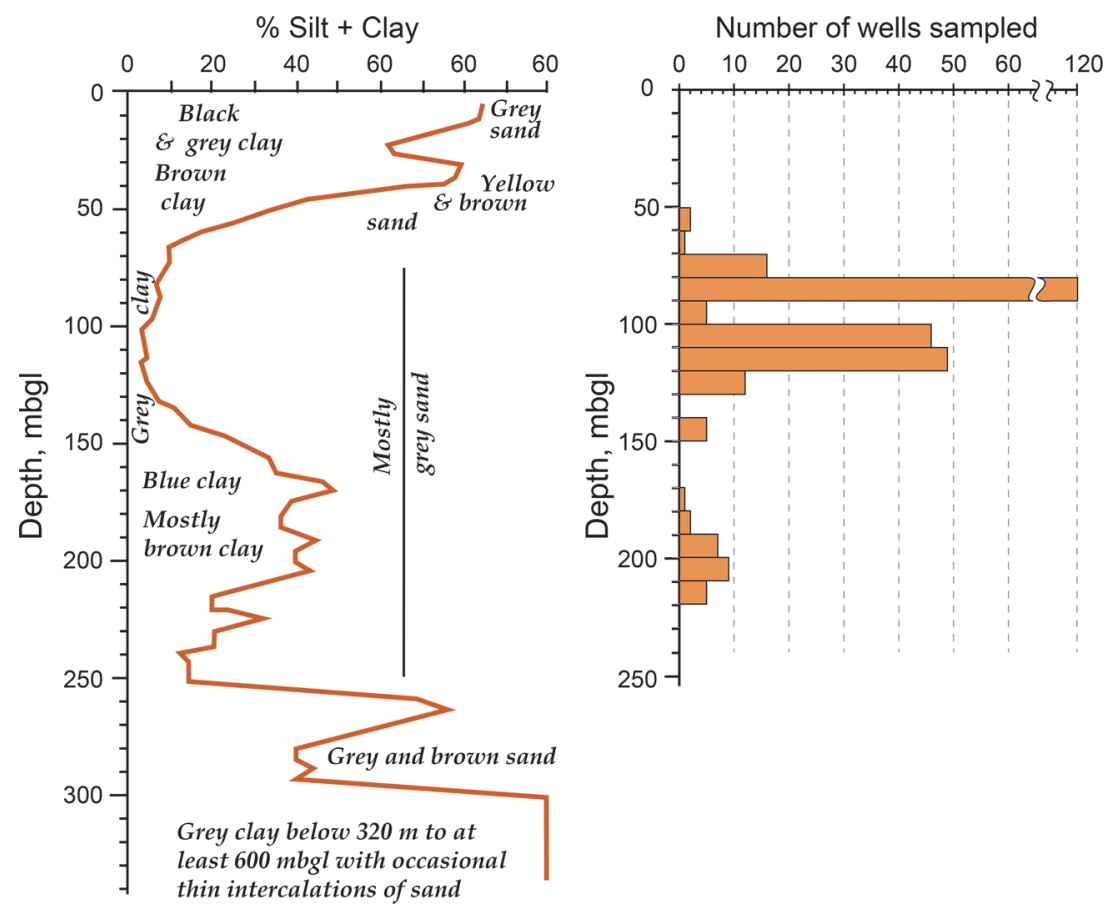

Figure 2. Composite lithological section compiled from 109 borehole logs used for Figure 5 (data from ref 38) together with a histogram of the number of wells sampled for this study compiled into $10 \mathrm{~m}$ bins using depths to midscreen.

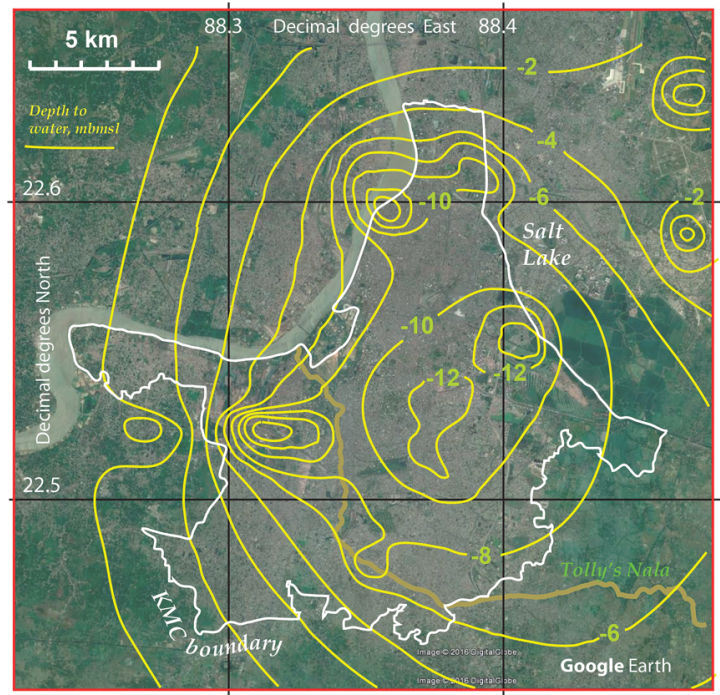

Figure 3. Modeled depth to the water table, relative to mean sea level, of groundwater beneath Kolkata outlining cones of depression caused by abstraction of groundwater for public supply. Model of ref 79; Table 2 of that reference gives measured water levels used to calibrate the model.

(location dependent) and brown above it. The sands are brown because they contain $\mathrm{Fe}(\mathrm{III})$-oxyhydroxides that resulted from a long period of oxidative weathering during the period of declining sea-level between 125 and 18 ka.9,18,26,27 The brown sand is capped by a hard, brown, lateritic clay, that is recognized as the LGMP. The top of the LGMP is at a median depth of 15 mbgl (mean depth $15.9 \mathrm{mbgl}$ ) and the median thickness is also $15 \mathrm{~m}$ (mean thickness $18.1 \mathrm{~m}$ ). Overlying the LGMP are floodplain silts and clays, with widespread peats between 3 and $5 \mathrm{~m}$ depth, and at $12 \mathrm{~m}$ depth.
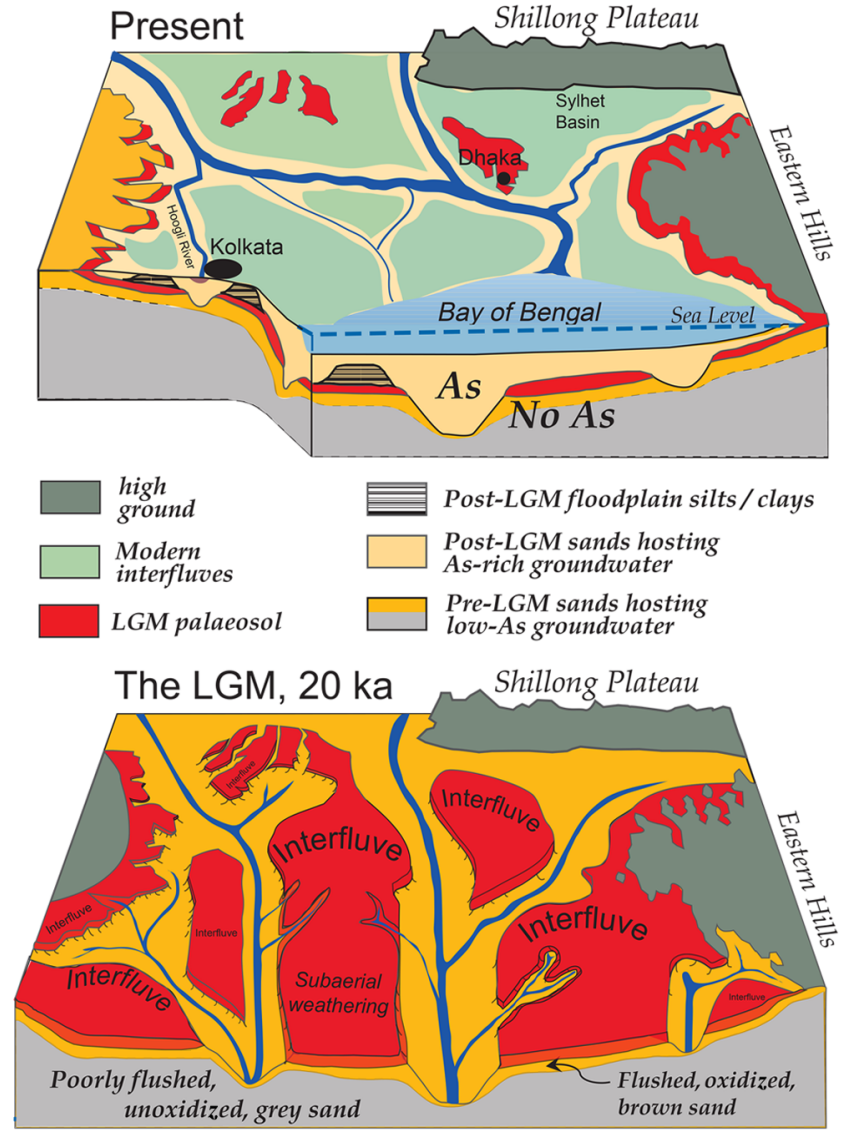

Figure 4. Schematic cross-section $\mathrm{E}-\mathrm{W}$ through the Bengal Basin, showing, not to scale, the approximate distribution of pre- and postLGM sediments. Pollution of groundwater by As is confined almost exclusively to post-LGM sediments. Updated from ref 29. 


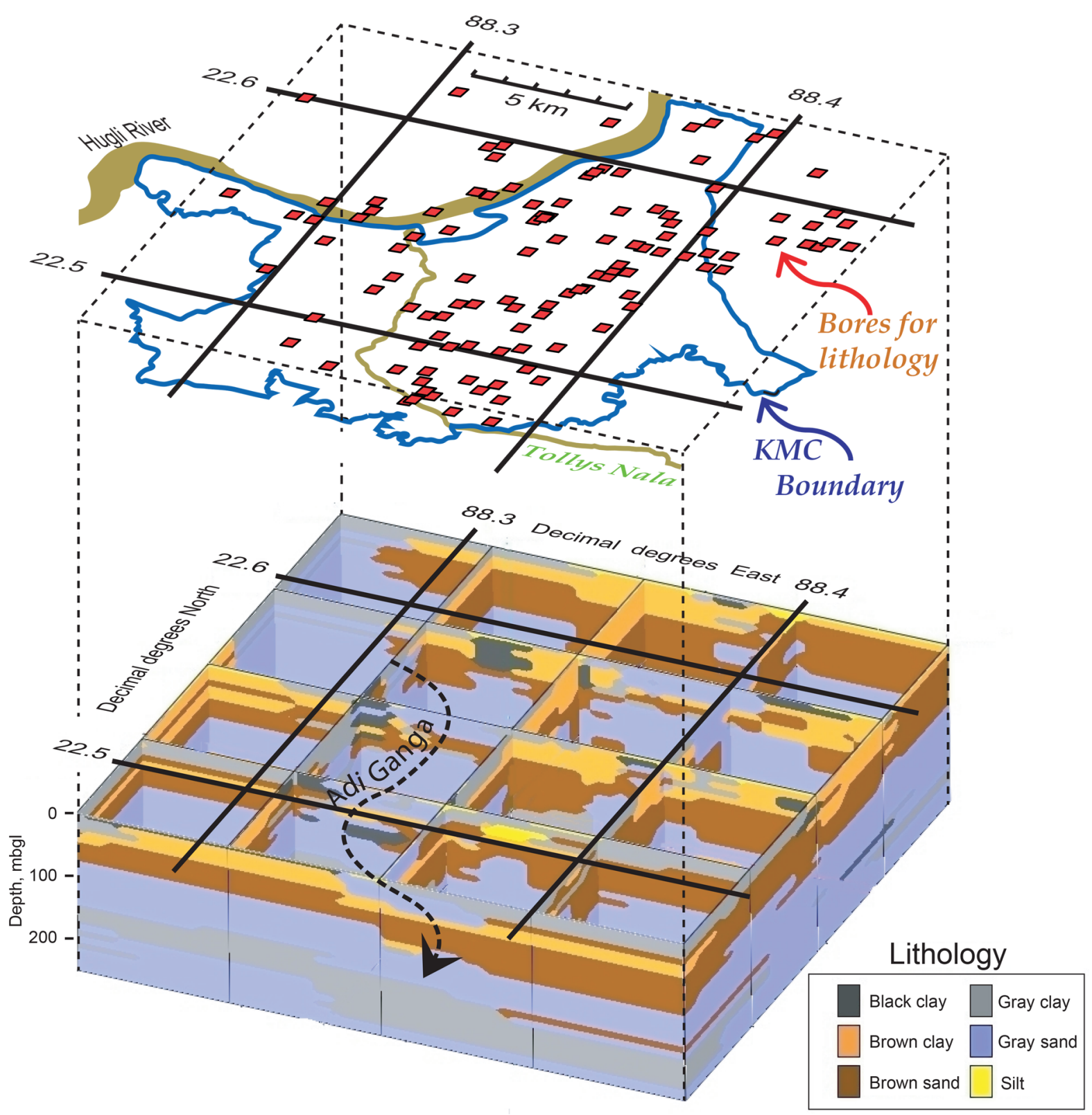

Figure 5. Geology beneath KMC and borehole locations $(n=109)$ used to map the distribution of facies. Borehole data from ref 38 . The deep palaeo-channel of the Adi Ganga, a previous course of the Hugli River, is shown as a dotted line in the lower part.

In $30 \%$ of borehole logs, no LGMP is recorded so Holocene river incision ${ }^{29,40}$ has thinned or removed it. As lithologies were recorded in units of $5 \mathrm{~m}$ thickness, beds $<5 \mathrm{~m}$ thick would have escaped detection including the LGMP. At $90 \%$ of sites where the LGMP is not recorded, thick brown sand is logged, so most such site probably have a thinned LGMP. These brown sands are typically overlain by a thick ( $\geq 5 \mathrm{~m}$ ) channel-fill of gray and/ or black clay. In a few sites, intercalated gray sands occur in the channel fill but, except for the instance detailed below, these are invariably underlain by clays $>5 \mathrm{~m}$ in thickness. The effect of this stratigraphy is to cap the late Pleistocene aquifer over most of the KMC with either thick Holocene clays or the LGMP, or both.

We identify one deep, late Pleistocene palaeo-channel. ${ }^{29,40}$ This marks the course of the Adi Ganga, a previous course of the Hugli River. The present Hugli River detours westward around the KMC. In past times, this detour was absent, and the river flowed south through the KMC in a late Pleistocene deep palaeo-channel. Along the width and length of this deep palaeochannel the LGMP was not developed. Gray sands filled the palaeo-channel as sea-level rose after the LGM. This deep palaeo-channel appears to run subparallel to, and possibly beneath much of, Tolly's Nala (Figure 5) and certainly crosses beneath it in south-central Kolkata (district of Behala). Where it does so it provides a direct route for surface water from Tolly's Nala to infiltrate the underlying late Pleistocene aquifer and bypass the upper aquitard that is present elsewhere. ${ }^{41}$

\section{ARSENIC IN KMC GROUNDWATER}

4.1. Arsenic Pollution under KMC. Of groundwaters from 280 wells, those from one municipal well (No. 33) and 13 public wells contained $>10 \mu \mathrm{g} / \mathrm{L}$ of As. An absence of Aspollution was expected because wells in the KMC are screened in late Pleistocene gray sands in which natural As-pollution is 


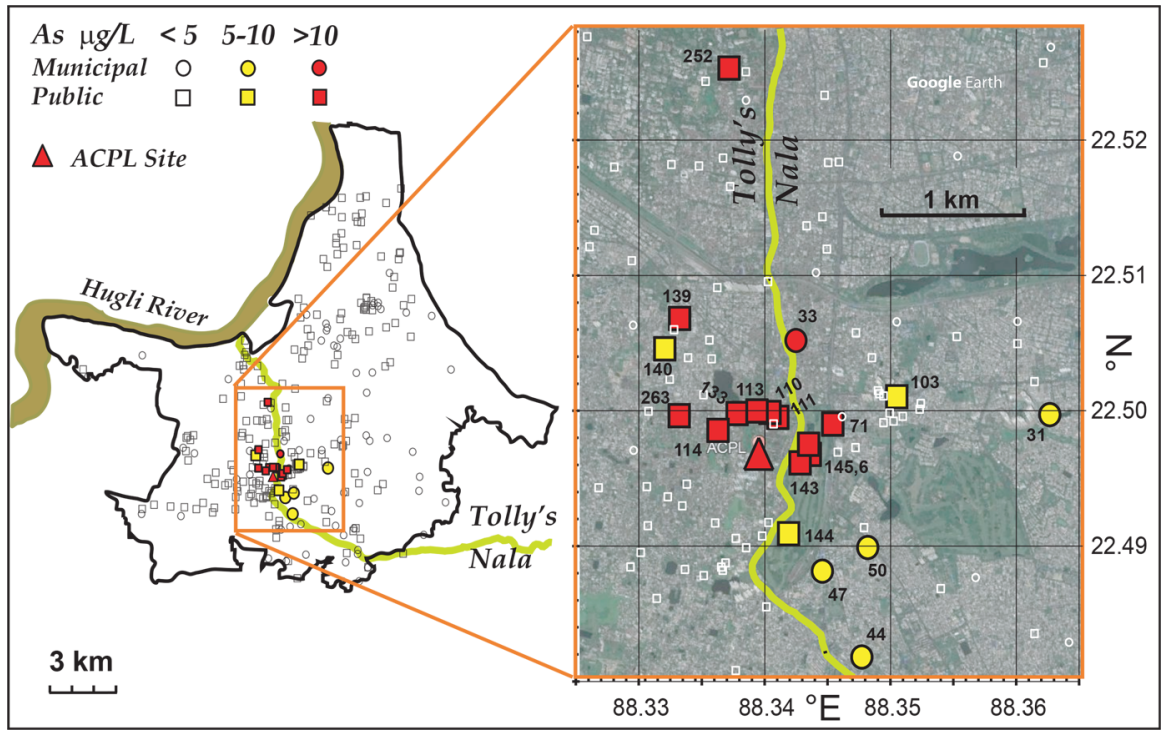

Figure 6. Distribution of As in groundwater beneath the KMC. Sample locations in Table S1. Groundwaters with $>5 \mu \mathrm{g} / \mathrm{L}$ As are close to Tolly's Nala and/or the ACPL factory site, where Paris green, an arsenical pesticide, was manufactured between 1965 and 1985.

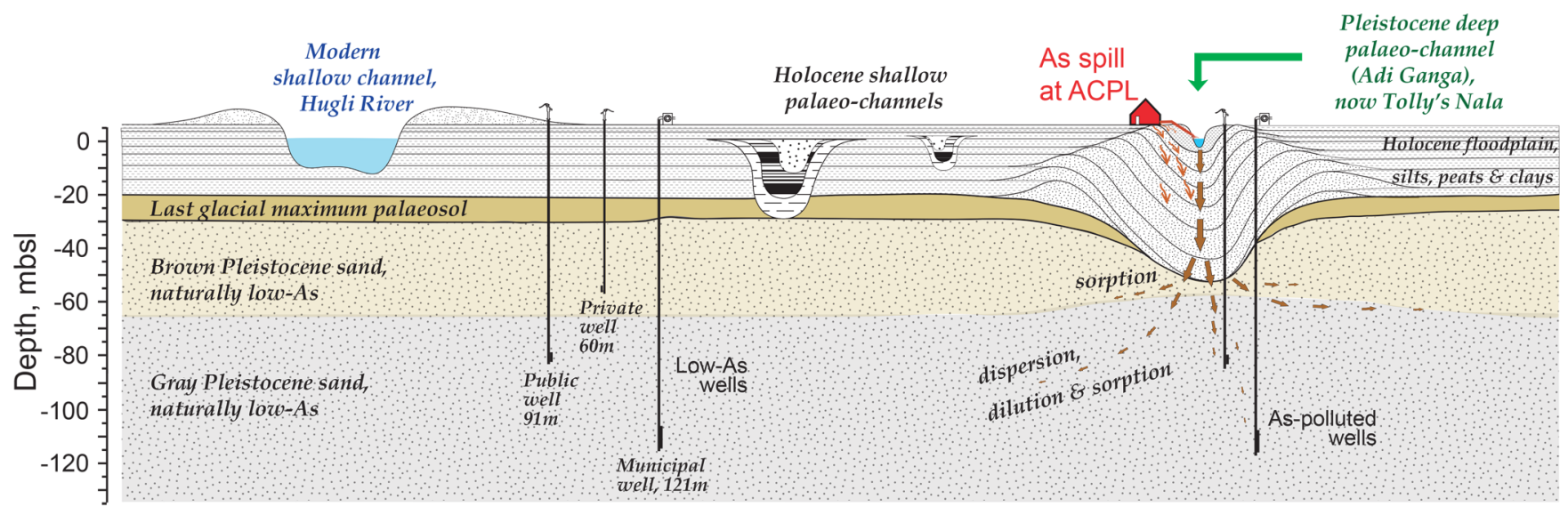

Figure 7. Schematic E-W cross-section through southern KMC, showing the disposition of major sedimentary units: floodplain deposits over a palaeosol over a late Pleistocene aquifer of brown sand over gray sand. Channels from Holocene river incision are filled largely by clays. One preglacial (deep) palaeo-channel marks the old course of the Adi Ganga river and is infilled with mostly sand, thereby forming a conduit for recharge to the late Pleistocene aquifer. The site of historical As-pollution at the ACPL factory is next to Tolly's Nala, which may be vestigial remnant of the Adi Ganga.

absent. The presence of As in 14 groundwater samples therefore needs explanation.

The As appears to be a remnant of past anthropogenic pollution. Between 1965 and 1985, Paris Green, an arsenical pesticide was made by Aceto-Chemical Private, Ltd. (ACPL hereinafter) at an industrial site in Behala, south-central Kolkata (Figures 1, 6, and 7). ${ }^{41-43}$ Groundwaters in 1993 close to the ACPL site were reported to have concentrations of As up to $39000 \mu \mathrm{g} / \mathrm{L}^{43}$ The ACPL site was located $200 \mathrm{~m}$ west of Tolly's Nala and was connected to it via a drain. ${ }^{41}$ Beneath parts of Tolly's Nala, e.g., at the ACPL site, the absence of the aquifer's usual capping aquitard (Figures 5 and 7) provides a pathway into the underlying aquifer for the As-pollution. ${ }^{41}$

No arsenic concentrations $>5 \mu \mathrm{g} / \mathrm{L}$ were found upflow (i.e. to the southwest of) the ACPL site, the direction from which As-pollution would arrive were As migrating to the site from Holocene aquifers outside of KMC. Groundwaters that contain As $>5 \mu \mathrm{g} / \mathrm{L}$ are found close to, or downflow of, either the ACPL site or Tolly's Nala (Figure 6). No other site yielding groundwater with $>10 \mu \mathrm{g} / \mathrm{L}$ is more than $900 \mathrm{~m}$ from the ACPL site or Tolly's Nala. The As concentrations $>10 \mu \mathrm{g} / \mathrm{L}$ reported in groundwater here appear to derive from the ACPL site. The initially severe local pollution sourced from the ACPL site is now barely detectable at the spatial scale at which we have sampled.

4.2. Arsenic's Route to the Aquifer under the KMC. The arsenic from the ACPL site was able to invade the late Pleistocene aquifer from Tolly's Nala through the window in the upper aquitard that exists where Tolly's Nala crosses the palaeo-channel of the Adi Ganga (Figures 5 and 7). Stable isotopic compositions of groundwaters reveals the extent of infiltration of river water. With trivial exceptions driven by local evaporation, the stable isotopic composition of groundwaters (Figure 8) plot along a linear array parallel to the local meteoric water line. ${ }^{44}$ The least-depleted groundwater compositions (3 to $-4 \%$ ) fall within the range of groundwaters in late Pleistocene aquifers elsewhere across the Bengal Basin. ${ }^{45}$ Waters from the Hugli River sampled here have $\delta^{18} \mathrm{O}$ values 


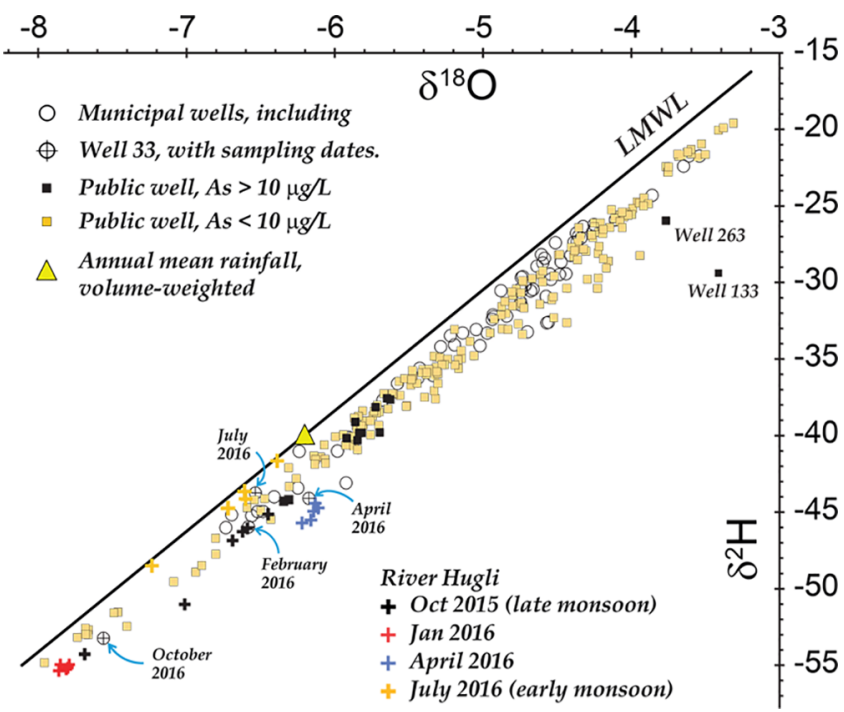

Figure 8. Isotopic compositions of groundwaters compared to the local meteoric water line, LMWL, for the region, ${ }^{44}$ which is essentially the same as the global MWL. Groundwaters plot along a mixing line between isotopically less-depleted late Pleistocene groundwaters with $\delta^{18} \mathrm{O}$ of around -3 to $-4 \%$, and river waters ranging from -6.1 to $-7.9 \%$.

between -6.1 and $-7.9 \%$, the values changing seasonally in response to varying proportions of base-flow, snowmelt, and rainfall-runoff, that reaches the river.

The least depleted $\delta^{18} \mathrm{O}$ value for Hugli River water is $-6.1 \%$. The volume-weighted mean annual value for $\delta^{18} \mathrm{O}$ of local rainfall is $-6.2 \%{ }^{44}$ Groundwaters with values more negative than this are found, with few exceptions, in two clusters close to Tolly's Nala. One is close to the ACPL site, the other is $1 \mathrm{~km}$ to the south at the major bend in Tolly's Nala (Figure 9). The proximity to Tolly's Nala of these sites suggests that infiltration to the late Pleistocene aquifer beneath $\mathrm{KMC}$ is occurring from Tolly's Nala. The array in Figure 8 thus results, in part, from mixing of isotopically depleted water from the River Hugli, via Tolly's Nala, with less-depleted groundwater. This connection is seen directly in Well 33 (Figure 6), which is sited $70 \mathrm{~m}$ east of Tolly's Nala and is screened at a depth of 102 to $122 \mathrm{mbgl}$. Groundwater composition for this well vary through the seasons (Figure 8) and the elemental and isotopic compositions for the groundwaters from Well 33 (Table S1) fall along a linear-mixing line reflecting this seasonal change in the proportion of river water and groundwater supplied by this well. We illustrate this mixing in Figure 10 using As $v \mathrm{Cl}$ concentrations. Similar linear (conservative) mixing is seen for most other constituents (Table S1), thus proving that this well is partly recharged by river-bank infiltration.

\section{RECONCILING CONFLICTING CLAIMS}

We find that there is no natural As-pollution of groundwater beneath the KMC and only a trace of anthropogenic Aspollution remnant from the ACPL site, although we caution that differences in scale make our findings not directly comparable to the initial small-scale survey ${ }^{43}$ at the ACPL site.

Our finding conflicts with the impression given by a published map of As pollution in groundwater beneath Kolkata $^{16}$ which shows $62 \%$ of the area of the KMC as being underlain by groundwater with $>10 \mu \mathrm{g} / \mathrm{L}$ of As. The map's basis is not clear and its implication conflicts with the claim ${ }^{16}$

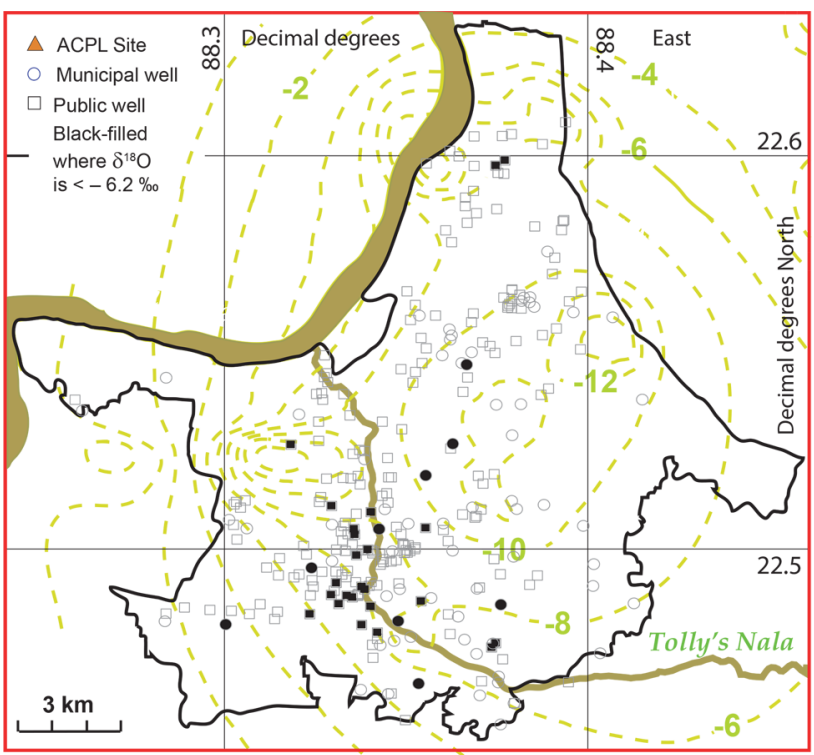

Figure 9. Map of the distribution of groundwaters with values of $\delta^{18} \mathrm{O}$ less than $-6.2 \%$, volume-weighted annual mean for $\delta^{18} \mathrm{O}$ in local rainfall. The isotopically light groundwater is located close to Tolly's Nala and cluster around the ACPL site and a site on Tolly's Nala about $1 \mathrm{~km}$ south of the ACPL site. This distribution proves the existence of a direct route for recharge between Tolly's Nala and the underlying late Pleistocene aquifer.

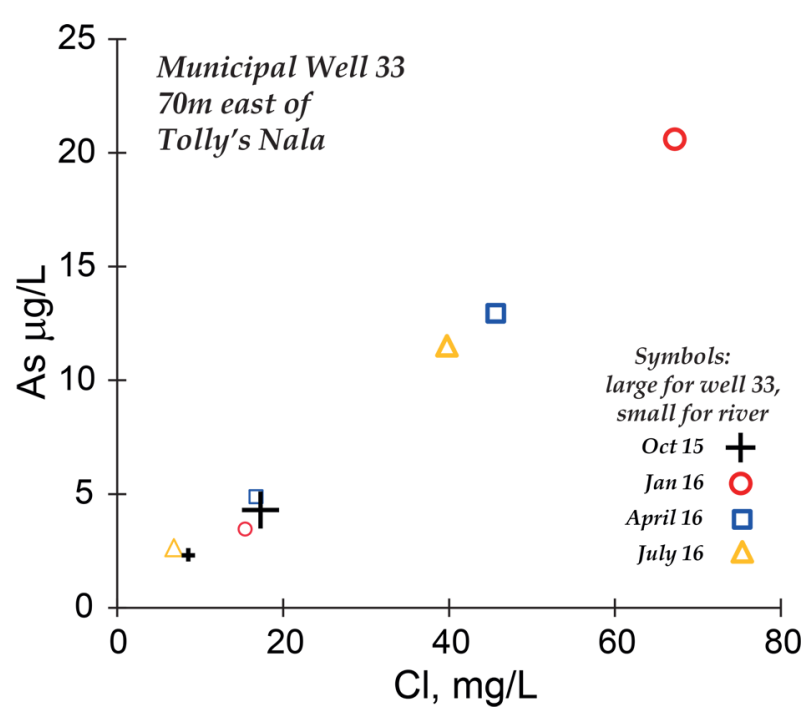

Figure 10. Seasonal changes in $\mathrm{As}$ and $\mathrm{Cl}$ in groundwater from Well 33, sited $70 \mathrm{~m}$ east of Tolly's Nala. Water from this well comprises varying proportions of groundwater and river water from Tolly's Nala. Linear mixing is shown by most constituents (Table S1). The mixing line shows that Well 33 is partly recharged by river-bank infiltration from Tolly's Nala. For river data, we use the river sample RC of Table S1, which was the nearest river sample to the confluence of the River Hugli and Tolly's Nala, some $2.0 \mathrm{~km}$ upstream of the confluence.

that groundwater containing $>10 \mu \mathrm{g} / \mathrm{L}$ of As was found only in $14 \%$ of 4,210 wells across KMC. The discrepancy cannot be resolved as no well locations are given, nor are they shown on the map. Another report ${ }^{17}$ of arsenic concentrations $>10 \mu \mathrm{g} / \mathrm{L}$ in groundwaters across $\mathrm{KMC}$, which contains only summary data, claims that As pollution has increased since 2009. How can these claims be reconciled with our data? 
Previous claims ${ }^{15-17}$ are not supported by data that could resolve the conflicts. Nevertheless, a resolution is possible. Regarding ref 17, no GPS locations of wells were reported but the authors provided to the writers the GPS coordinates of three (their numbers 55, 56, and 57). We analyzed groundwaters we collected from Wells 56 and 57 (55 was defunct in early 2017). Data are, in $\mu \mathrm{g} / \mathrm{L}$ :

ref 17 No. 56: As = $41 \mathrm{Fe}=1,626$;

Same well, this work, (our 249): As $=1.2, \mathrm{Fe}=3700$.

ref 17 No. 57: As $=14, \mathrm{Fe}=128$.

Same well, this work, (our 247): As $=1.1, \mathrm{Fe}=6800$.

For ref 17, ICP-AES was used to quantify As concentration without specifying analytical conditions; no quantitation limit was reported. For ICP-AES it is typically between 10 and 100 $\mu \mathrm{g} / \mathrm{L}$ depending on instrument make, maintenance schedule, and operating mode. This work used ICP-MS with a quantitation limit around $1 \mu \mathrm{g} / \mathrm{L}$. We therefore regard the summary data of ref 17 as being erroneous because they were obtained using an analytical method insufficiently sensitive for the task undertaken. We discount the possibility that those authors sampled mainly the limited occurrence of shallow palaeo-channel aquifers beneath Kolkata, and our essentially random sampling did not. Our analysis of the geology underlying Kolkata (Figures 2 and 5), and the number of wells we sampled, restricts this likelihood severely. Moreover, the claim ${ }^{17}$ that As-pollution has increased since 2009 would be valid only if the authors of that work had sampled the same wells as had the authors of ref 15 and found that As concentrations in those wells had increased. There is no indication that they did so.

Regarding the apparently contradictory claim that $14 \%$ of $\mathrm{KMC}$ wells gave groundwater with $>10 \mu \mathrm{g} / 1$ As while $62 \%$ of the area under Kolkata is As-polluted, ${ }^{16}$ the SI for ref 16 reveals that $57 \%$ of the samples were collected prior to 1999 and $86 \%$ were collected prior to 2009. It follows that, irrespective of inconsistency, this publication does not reflect the current hazard posed by As in KMC's groundwater.

\section{FATE OF ANTHROPOGENIC AS}

What is the fate of the anthropogenic As-pollution spilled at the ACPL site? The schematic cross-section through the ACPL site shown in Figure 7 suggests that, since the ACPL site closed in 1985 , >30 years of dilution and dispersion has lowered the concentration of As in groundwater. Second, sorption to brown and gray late-Pleistocene aquifer sands will have contributed to the removal of As from groundwater. ${ }^{31,46-48}$ Third, As substitutes for $S$ in pyrite ${ }^{49-53}$ so sequestration of As into pyrite has been invoked repeatedly as a sink for As in order to explain unexpectedly low concentrations of As in anoxic groundwaters. ${ }^{54-59}$ The ACPL factory made Paris Green, $\left(\mathrm{Cu}\left[\mathrm{CH}_{3} \mathrm{COO}\right]_{2} \cdot 3 \mathrm{Cu}\left[\mathrm{AsO}_{2}\right]_{2}\right)$, which contains acetate, so the factory effluent would likely have contained acetate or acetic acid, microbial oxidation of which would have promoted the reduction of $\mathrm{SO}_{4}$ in the pollution plume and contributed to pyrite formation. That sulfate reduction has occurred in groundwaters is shown by the fact that salt-corrected concentrations of $\mathrm{SO}_{4}$ are in deficit by up to $110 \mathrm{mg} / \mathrm{L}$ (Figure S2a). To achieve this amount of reduction requires 28 $\mathrm{mg} / \mathrm{L}$ of DOC. Sulfate in excess is now found in fresher groundwaters bordering Tolly's Nala (Figure S2a), thus emphasizing the temporal element of the As-pollution; older water is deficient in $\mathrm{SO}_{4}$ while younger water is enriched in $\mathrm{SO}_{4}$ and found mostly in the vicinity of Tolly's Nala (Figure S2b).

\section{OTHER ELEMENTS}

7.1. Copper. Paris Green contains copper. Although Paris Green has a very limited solubility in water, the $\mathrm{Cu}$ salts used to make it were likely more soluble. Yet only two groundwaters contain $>10 \mu \mathrm{g} / \mathrm{L} \mathrm{Cu}(179$ and $12 \mu \mathrm{g} / \mathrm{L}$ for Wells 180 and 258). Neither are near Tolly's Nala or the ACPL site. Copper substitutes well into pyrite, so we hypothesize that either little $\mathrm{Cu}$ salt accompanied the As-pollution emanating from the ACPL site, or that $\mathrm{Cu}$ that might have contaminated groundwater between 1965 and 1985 has been removed by dilution, dispersion, and sulfide formation.

7.2. Manganese. The presence of $\mathrm{Mn}$ in groundwater may be a hazard to health, especially for children. ${ }^{60-64}$ The element is present in both Holocene and late Pleistocene aquifers across the Bengal and other Asian deltaic aquifers. ${ }^{18,19,65,66}$ Despite this hazard, no Guideline Value (GV) for Mn was set by the World Health Organization ${ }^{67}$ in 2017 although " $A$ health-based value of $0.4 \mathrm{mg} / \mathrm{L}$ can be derived for manganese based on the upper range value of manganese intake of $11 \mathrm{mg} /$ day". Prior to 2011, WHO did set a GV of $0.4 \mathrm{mg} / \mathrm{L}$.

Of the wells we sampled in Kolkata, $37 \%$ of municipal wells and $47 \%$ of public wells give groundwater with concentration of $\mathrm{Mn}>0.4 \mathrm{mg} / \mathrm{L}$ and concentrations range up to $1.4 \mathrm{mg} / \mathrm{L}$ with one outlier at $2.8 \mathrm{mg} / \mathrm{L}$ (Table S1). Only one municipal well (No. 33) contains $>1 \mathrm{mg} / \mathrm{L} \mathrm{Mn}$. Thus, for residents of the $\mathrm{KMC}$, the hazard to health from $\mathrm{Mn}$ in groundwater may be greater than the hazard from As. The Mn concentrations are higher than those of 0.1 to $0.4 \mu \mathrm{g} / \mathrm{L}$ that are typically found in groundwaters from late Pleistocene gray sands elsewhere in the Bengal Basin. ${ }^{18,19,45}$ They are, however, comparable to $\mathrm{Mn}$ concentrations found in late Pleistocene brown sands, which typically range between 0.2 and $1 \mathrm{mg} / \mathrm{L}$ except in the vicinity of roll-fronts of redox where $\mathrm{Fe}$ and $\mathrm{Mn}$ oxides are mobilized and drive $\mathrm{Mn}$ concentrations up to $6 \mathrm{mg} / \mathrm{L} .{ }^{33,65}$

Concentrations of $\mathrm{Mn}>1 \mathrm{mg} / \mathrm{L}$ appear to form a circular distribution emanating from the ACPL site; the distribution could be interpreted as a redox front progressing downflow from the ACPL site (Figure S3). The highest $\mathrm{Mn}$ concentrations occur at around $80 \mathrm{~m}$ depth (Figure 11c), as do Fe concentrations (Figure $11 \mathrm{~b}$ ), but the Mn concentrations decline at increasing depth below $60 \mathrm{~m}$ more slowly than do those of $\mathrm{Fe}$, again suggesting a redox front of $\mathrm{Mn}$-reduction progressing ahead of an Fe-reduction front.

7.3. Iron. In groundwater from late Pleistocene aquifers of the Bengal Basin, of both gray and brown sand, concentrations of $\mathrm{Fe}>3 \mathrm{mg} / \mathrm{L}$ are uncommon. ${ }^{18,19,45}$ In contrast, beneath the KMC concentrations of $\mathrm{Fe}>10 \mathrm{mg} / \mathrm{L}$ are common and are concentrated around and to the north of the ACPL site (Figure S3). The highest concentrations of up to $23 \mathrm{mg} / \mathrm{L}$ are at $80 \mathrm{~m}$ depth (Figure $11 \mathrm{~b}$ and Table S1). Concentrations $>10 \mathrm{mg} / \mathrm{L}$ indicate influx to the aquifer of a reducing agent of unusual power or concentration; we speculate that it was acetate from the ACPL site. Although organic matter from sewage disposal into Tolly's Nala might contribute to reduction, the data suggest the effect is minor because, around $1 \mathrm{~km}$ south along Tolly's Nala from the ACPL site, the stable isotope data (Figure 9) reveal a window into the late Pleistocene aquifer for water from Tolly's Nala, yet in that vicinity Fe concentrations $>10$ $\mathrm{mg} / \mathrm{L}$ are all but absent (Figure S3).

7.4. Other Trace Elements. With the exception of $\mathrm{Mn}$, few elements of health concern ${ }^{67}$ are present in amounts that pose a serious threat to consumers, although local, minor, hazards 


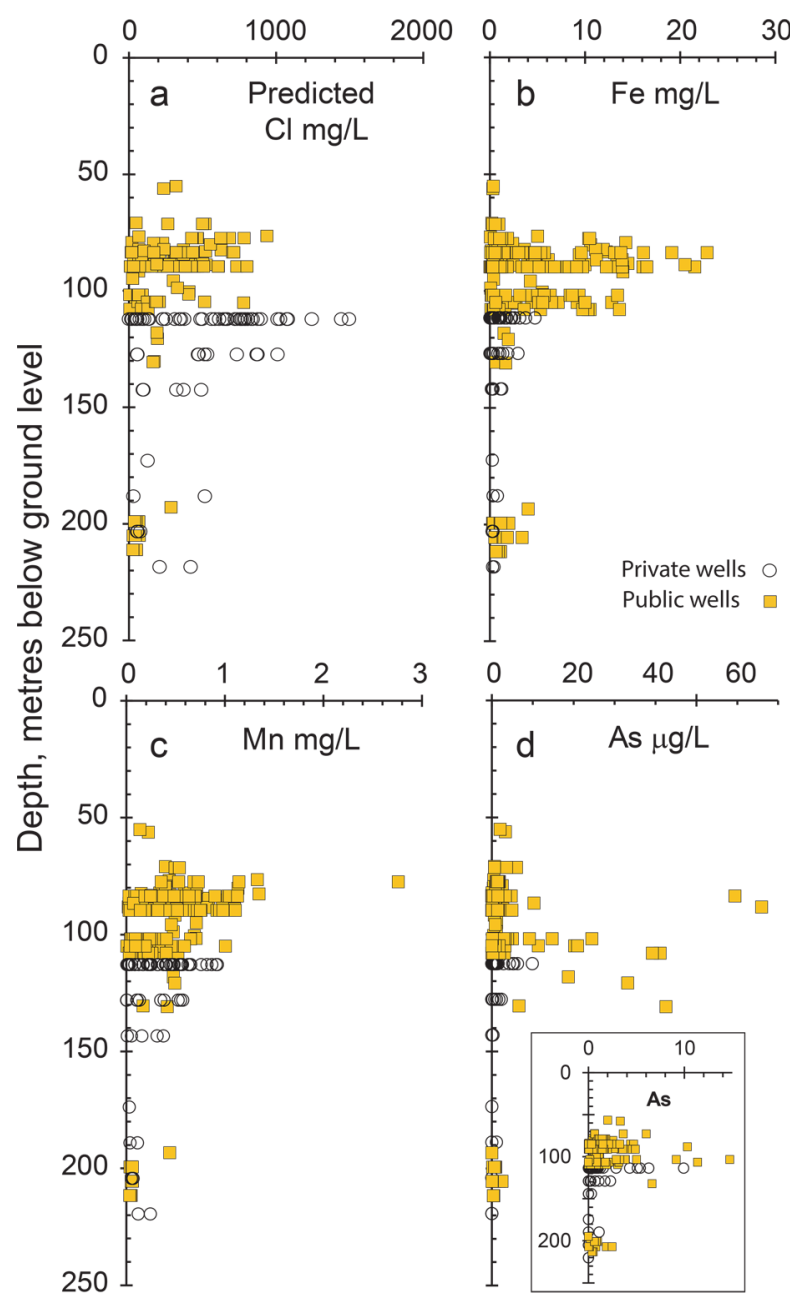

Figure 11. Depth profiles of Predicted-Cl (a), Fe (b), Mn (c), and As (d), in groundwater beneath the Kolkata Municipal Corporation. Depths given to midscreen. Predicted-Cl is $\mathrm{Cl}$ predicted from $\mathrm{Br}$ concentrations, a measure that emphasizes the influence of marinederived waters by removing anthropogenic $\mathrm{Cl}$. Values are not plotted for the 24 groundwaters with $\mathrm{Cl} / \mathrm{Br}$ below the marine-mixing line in Figure 12a.

exist. They are summarized here and discussed more fully in SI Section S3. Nitrate is present at concentrations $>0.5 \mathrm{mg} / \mathrm{L}$ only in groundwater from motorized wells (5 municipal, one private), of which 3 are $<200 \mathrm{~m}$ from Tolly's Nala; all have values of $\delta^{18} \mathrm{O}$ more negative than $-5.9 \%$. Concentrations of $\mathrm{F}$ are between 0.75 and $1 \mathrm{mg} / \mathrm{L}$ in 10 groundwaters and are inversely related to Ca concentrations, suggesting a control by equilibria with a Ca-mineral, possibly fluorite or apatite (Figure S4). Sodium concentrations have been increased by ionexchange with $\mathrm{Ca}$ (Figure S5a); Na concentrations $>500 \mathrm{mg} / \mathrm{L}$ (mostly in western KMC; Figure S5b) might promote hypertension in consumers. ${ }^{68-70}$ If hazards from As $(>10 \mu \mathrm{g} /$ $\mathrm{L})$ and $\mathrm{Mn}(>0.4 \mathrm{mg} / \mathrm{L})$ are compounded with uncommon hazards from $\mathrm{F}$ ( 10 wells, assuming a GV of $0.75 \mathrm{mg} / \mathrm{L}$ ), common high $\mathrm{Na}(>500 \mathrm{mg} / \mathrm{L})$, and minor exceedances for $\mathrm{Pb}$ $(>10 \mu \mathrm{g} / \mathrm{L})$, then $64 \%$ of public wells and $40 \%$ of municipal wells are supplying groundwater of questionable quality because of one or more of these species.

7.5. Chloride. High concentrations of $\mathrm{Cl}$ in groundwater beneath large cities is often taken to indicate the presence in groundwater of sewage effluent, which typically contains $\mathrm{Cl}$ concentrations in the range $300-600 \mathrm{mg} / \mathrm{L}^{59,71,72}$ In coastal settings, high $\mathrm{Cl}$ could also derive from salt-water either via modern intrusion or from brackish connate water. Marine and anthropogenic influences can be distinguished using $\mathrm{Cl} / \mathrm{Br}$ values $^{71-73}$ and these are shown in Figure 12a.
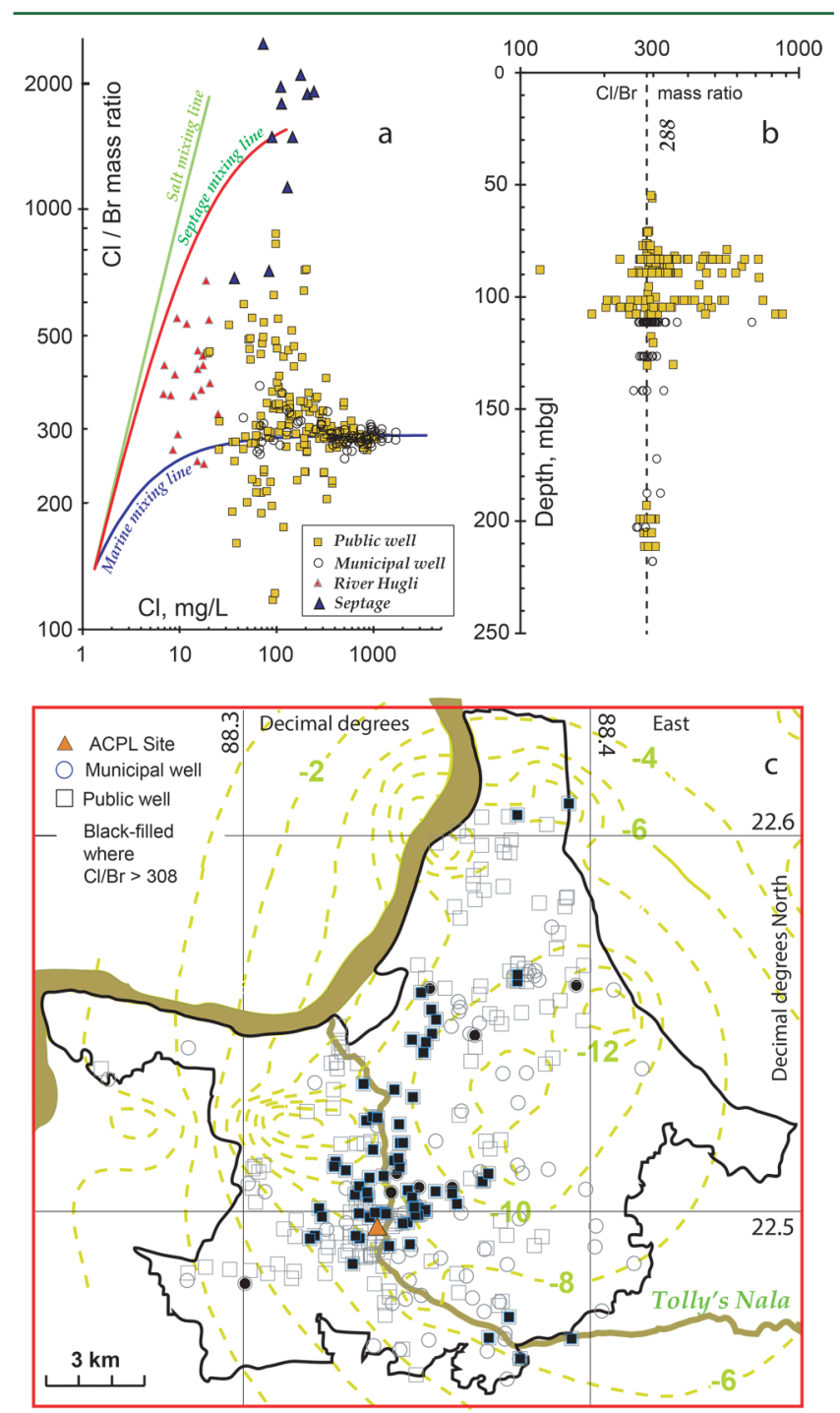

Figure 12. (a) Cross plot of $\mathrm{Cl}$ and $\mathrm{Cl} / \mathrm{Br}$ in groundwater beneath the KMC and for septage in West Bengal. ${ }^{59}$ Groundwaters contaminated by sewage and septage plot above the marine-mixing line; (b) depth, to midscreen, of $\mathrm{Cl} / \mathrm{Br}$; values $>308$ are not present beneath $110 \mathrm{~m}$ depth-we use 308 rather than the marine value of 288 to allow for analytical uncertainty; and (c) distribution across $\mathrm{KMC}$ of $\mathrm{Cl} / \mathrm{Br}$ of groundwater, showing that most $\mathrm{Cl} / \mathrm{Br}$ values $>308$ occur close to Tolly's Nala.

Around $10 \%$ of groundwaters plot below the marine-mixing line; most are at a depth around $105 \mathrm{mbgl}$ (Figure 12b). These groundwaters contain excess $\mathrm{Br}$ from organic degradation. ${ }^{59,74,75} \mathrm{~A}$ further $33 \%$ of public wells and $14 \%$ of municipal wells plot above the marine-mixing line and are contaminated by $\mathrm{Cl}$ of anthropogenic origin (Figure 12a; Table $\mathrm{S} 1 ; \mathrm{Cl} / \mathrm{Br}>$ 308 , the upper limit of $288 \pm 20$, to allow for analytical uncertainty). These figures are lower limits, as small additions of high- $\mathrm{Cl}$ sewage effluent would be masked by the high $\mathrm{Cl}$ concentration of many groundwaters $(>500 \mathrm{mg} / \mathrm{L})$. Depth profiles of $\mathrm{Cl} / \mathrm{Br}$ (Figure 12b) shows that little surface 
contamination by anthropogenic $\mathrm{Cl}$ has been drawn down to below $110 \mathrm{~m}$ depth by pumping; wells deeper than $110 \mathrm{~m}$ remain unaffected by surface-derived $\mathrm{Cl}$, and so, by implication, other surface derived pollution given that $\mathrm{Cl}$ is more mobile in groundwater than are other contaminants or pollutants. Most of the groundwaters plot close to the marine mixing-line, proving that their $\mathrm{Cl}$ is derived from seawater (or brackish water of marine origin), rather than being of anthropogenic origin. $^{59}$ The depth profile of predicted-Cl, i.e. $\mathrm{Cl}$ concentrations predicted from $\mathrm{Br}$ so discounting anthropogenic $\mathrm{Cl}$ (Figure 11a), shows that the interval 80 to $120 \mathrm{mbgl}$ is the most affected by seawater.

Although elevated $\mathrm{Cl} / \mathrm{Br}$ is seen in scattered localities elsewhere across KMC, most elevated values are located in south central Kolkata near the ACPL site and along Tolly's Nala (Figure $12 \mathrm{c}$ ). This is unsurprising, as it is in the vicinity of the ACPL site that river incision along Tolly's Nala provides a conduit from the surface to the underlying late Pleistocene aquifer. The implication for groundwater supply is that wells should not be located near the intersection of the Adi Ganga palaeo-channel and Tolly's Nala. Until the subsurface route and extent of the Adi Ganga palaeo-channel is better known, the precautionary principle suggests that wells in Behala and all near Tolly's Nala should be tested for known surface-derived contaminants/pollutants.

\section{COMPARISONS TO OTHER ASIAN MEGACITIES}

The sedimentological setting of Kolkata is similar to the setting of the megacity of Dhaka, Bangladesh. Both cities exploit a late Pleistocene aquifer protected from downward movement of pollution by a thick upper aquitard. The major difference is that for Dhaka, the city sits directly on an equivalent of the LGMP, whereas Kolkata sits on thick floodplain silts, clays, and peats, that in turn mostly sit on the LGMP. Both cities have a local short-circuit that connects the aquifer to the surface. In Dhaka, it is a fault at the city's western side that throws the top of the late Pleistocene aquifer into the bed of the River Buriganga, so allowing river-bed infiltration to contribute to recharge of the late Pleistocene aquifers beneath the city. ${ }^{45}$ In Kolkata, it is, possibly, Tolly's Nala; it is certainly the point where the palaeochannel of the Adi Ganga crosses Tolly's Nala. In contrast to Dhaka and Kolkata, the city of Hanoi exploits Holocene and late Pleistocene aquifers that are shallower (typically $<70 \mathrm{~m}$ depth), more connected vertically and laterally, and wellconnected to surface sources of recharge such as the Red River. $^{8,76,77}$ The open system under Hanoi has resulted in widespread As-pollution occurring in the aquifers beneath the city.

\section{CONCLUSIONS}

1. For groundwater supply, Kolkata exploits a late Pleistocene aquifer of brown over gray sands that sits beneath a late Pleistocene palaeosol, termed the last glacial maximum palaeosol.

2. In common with late Pleistocene aquifers across the Bengal Basin, the groundwater in the late Pleistocene aquifer beneath Kolkata is not polluted by naturally occurring As.

3. A deep palaeo-channel cuts north-to-south through southern Kolkata and marks the course of the ancient Adi Ganga river, a precursor to the present Hugli River that now flows in a channel to the west of the Adi Ganga palaeo-channel.

4. In the vicinity of Tolly's Nala, a minor distributary channel of the River Hugli, river incision has cut into the palaeo-channel sands of the Adi Ganga and connects the late Pleistocene aquifer to the surface waters in Tolly's Nala, forming a recharge window into the aquifer.

5. Between 1965 and 1985, a factory making Paris Green, an arsenical pesticide, was sited directly on the window into the late Pleistocene aquifer. Arsenic from the factory polluted groundwater. That pollution has now almost vanished from the groundwater through a combination of dilution, dispersion, absorption, and sequestration into pyrite.

6. Values of $\mathrm{Cl} / \mathrm{Br}$ reveal that surface contamination of $\mathrm{Cl}$ has penetrated to $110 \mathrm{~m}$ depth.

7. Of groundwaters sampled from beneath Kolkata, $45 \%$ contained $>0.4 \mathrm{mg} / \mathrm{L}$ of $\mathrm{Mn}$, so naturally occurring $\mathrm{Mn}$ poses a bigger threat to health than does As.

Our finding that natural As-pollution appears to be absent from Kolkata's groundwater clarifies and downgrades previous claims of wide pollution by As beneath the city. The apparent conflict between these previous claims and our data illustrates the need for an understanding of the aquifer under investigation when undertaking a water-quality investigation. Credibility may have been given to the apparent presence of natural As-pollution in KMC groundwater ${ }^{15-17}$ because such a finding would have been consistent with the common As-pollution in Holocene, shallow, aquifers around Kolkata. Had it been known that the aquifer beneath Kolkata is late Pleistocene in age and unpolluted elsewhere in the Bengal Basin, these previous interpretations might have been different.

Those previous reports ${ }^{15-17}$ might also have been interpreted differently had they contained the data on which they were based and had they given full details of analytical methods. With such information, one ${ }^{17}$ might have had its methodology questioned in review. Two others ${ }^{15,16}$ might have established that the As pollution was anthropogenic and waning. No better examples could be found of the need for scientific reports to contain all of the data on which they are based.

\section{ASSOCIATED CONTENT}

\section{S Supporting Information}

The Supporting Information is available free of charge on the ACS Publications website at DOI: 10.1021/acs.est.7b04996.

Tables and supporting figures showing well-locations and the chemical and stable isotopic composition of groundwater (PDF)

\section{AUTHOR INFORMATION}

\section{Corresponding Author}

*Phone: +44 (0)203 108 6362; e-mail: j.mcarthur@ucl.ac.uk (J.M.M.).

\section{ORCID}

J. M. McArthur: 0000-0003-1461-7805

Notes

The authors declare no competing financial interest.

\section{ACKNOWLEDGMENTS}

We thank Carol Arrowsmith for performing the stable isotope analysis at NIGL (which is funded by NERC), David Waite for 
obtaining peer review, and Peter Knappett and an anonymous reviewer for constructive comments that improved the presentation of this work.

\section{REFERENCES}

(1) Falkenmark, M.; Widstrand, C. Population and water resources: a delicate balance. Popul. Bull. 1992, 47, 1-36.

(2) Foster, S.; Hirata, R.; Howard, K. Groundwater use in developing cities: policy issues arising from current trends. Hydrogeol. J. 2011, 19, $271-274$.

(3) Lundqvist, J.; Appasamy, P.; Nelliyat, P. Dimensions and approaches for Third World city water security. Philos. Trans. R. Soc., B 2003, 358, 1985-1996.

(4) McDonald, R.; Douglas, I.; Revenga, C.; Hale, R.; Grimm, N.; Gronwall, J.; Fekete, B. Global urban growth and the geography of water availability, quality, and delivery. Ambio 2011, 40, 437-446.

(5) Galloway, D.; Burbey, T. Regional land subsidence accompanying groundwater extraction. Hydrogeol. J. 2011, 19, 1459-1486.

(6) Hoque, M. A.; Hoque, M. M.; Ahmed, K. M. Declining groundwater level and aquifer dewatering in Dhaka metropolitan area, Bangladesh: causes and quantification. Hydrogeol. J. 2007, 15, 15231534.

(7) Hosono, T.; Nakano, T.; Shimizu, Y.; Onodera, S.; Taniguchi, M. Hydrogeological constraints on nitrate and arsenic contamination in Asian metropolitan groundwater. Hydrological Processes 2011, 25, $2742-2754$

(8) Berg, M.; Tran, H. C.; Nguyen, T. C.; Pham, H. V.; Schertenleib, R.; Giger, W. Arsenic contamination of ground and drinking water in Vietnam: a human health threat. Environ. Sci. Technol. 2001, 35, 26212626.

(9) Ravenscroft, P.; Brammer, H.; Richards, K. S. Arsenic Pollution: A Global Synthesis; Wiley-Blackwell: New York, 2009; 588 pp.

(10) Knappett, P. S. K.; Mailloux, B. J.; Choudhury, I.; Khan, M. R.; Michael, H. A.; Barua, S.; Mondal, D. R.; Steckler, M. S.; Akhter, S. H.; Ahmed, K. M.; Bostick, B.; Harvey, C. F.; Shamsudduha, M.; Shuai, P.; Mihajlov, I.; Mozumder, R.; van Geen, A. Vulnerability of low-arsenic aquifers to municipal pumping in Bangladesh. J. Hydrol. 2016, 539, 674-686.

(11) Pal, T.; Mukherjee, P. K.; Sengupta, S. Nature of arsenic pollutants in groundwater of Bengal Basin - a case study from Baruipur area, West Bengal, India. Curr. Sci. 2002, 82 (5), 554-561.

(12) Hoque, M. A.; McArthur, J. M.; Sikdar, P. K. The palaeosol model of arsenic pollution of groundwater tested along a $32 \mathrm{~km}$ traverse across West Bengal, India. Sci. Total Environ. 2012, 431, 157165.

(13) Sahu, P.; Michael, H. A.; Voss, C. I.; Sikdar, P. K. 2013. Impacts on groundwater recharge areas of megacity pumping: analysis of potential contamination of Kolkata, India, water supply. Hydrol. Sci. J. 2013, 58 (6), 1340-1360.

(14) Sahu, P.; Sikdar, P. K.; Chakraborty, S. Geochemical evolution of groundwater in southern Bengal Basin: The example of Rajarhat and adjoining areas, West Bengal, India. J. Earth Syst. Sci. 2016, 125 (1), 129-145.

(15) Chakraborti, D.; Das, B.; Rahman, M. M.; Chowdhury, U. K.; Biswas, B.; Goswami, A. B.; Nayak, B.; Pal, A.; Sengupta, M. K.; Ahamed, S.; Hossain, A.; Basu, G.; Roychowdhury, T.; Das, D. Status of groundwater arsenic contamination in the state of West Bengal, India: A 20-year study report. Mol. Nutr. Food Res. 2009, 53, 542-551.

(16) Chakraborti, D.; Das, B.; Rahman, M. M.; Nayak, B.; Pal, A.; Sengupta, M. K.; Ahamed, S.; Hossain, Md. A.; Chowdhury, U. K.; Biswas, B. K.; Saha, K. C.; Dutta, R. N. Arsenic in groundwater of the Kolkata Municipal Corporation (KMC), India: critical review and modes of mitigation. Chemosphere 2017, 180, 437-447.

(17) Malakar, A.; Islam, S.; Ali, Md. A.; Ray, S. Rapid decadal evolution in the groundwater arsenic content of Kolkata, India and its correlation with the practices of her dwellers. Environ. Monit. Assess. 2016, 188, 188-584.
(18) DPHE. Groundwater Studies for Arsenic Contamination in Bangladesh. Phase I: Rapid Investigation; Department of Public Health Engineering (DPHE) of Government of Bangladesh, British Geological Survey (BGS) and Mott MacDonald Ltd (MML): United Kingdom, 1999.

(19) DPHE. Arsenic Contamination of Groundwater in Bangladesh; Kinniburgh, D. G., Smedley, P. L. Eds.; Department of Public Health Engineering (DPHE) of Government of Bangladesh and British Geological Survey (BGS): Keyworth, 2001; 267 pp.

(20) Choudhury, I.; Ahmed, K. M.; Hasan, M.; Mozumder, M. R. H.; Knappett, P. S. K.; Ellis, T.; van Geen, A. Evidence for elevated levels of arsenic in public wells of Bangladesh due to improper installation. Groundwater 2016, 54 (6), 871-877.

(21) Census of India, West Bengal, District Census Handbook, Kolkata, Primary Census Abstract. Series 20, Part XII B, 2011.

(22) Chatterjee, A. Water Supply system in Kolkata city and adjoining areas. 2014, https://medium.com/@anjan.chatterjee/watersupply-system-in-kolkata-city-and-adjoining-areas-b199099a4517\#. trpdgul6z, Accessed on 23.07.2016.

(23) Chakrabarti, C.A Source Book of Environment of Kolkata; Kolkata Municipal Corporation: Kolkata, 2013; 204 pp.

(24) Maity, B. K. Management of Urban Water Cycle in Kolkata Municipal Corporation. http://www.bengalchamber.com/ energyconclave/year2012/b-k-maiti.pdf, 2012, Accessed on 23/07/ 2016.

(25) Umitsu, M. Late Quaternary sedimentary environments and landforms in the Ganges Delta. Sediment. Geol. 1993, 83, 177-186.

(26) Stanley, D. J.; Hait, A. H. Holocene depositional patterns, neotectonics and Sundarban mangroves in the western GangesBrahmaputra delta. J. Coastal Res. 2000, 16, 26-39.

(27) Goodbred, S. L., Jr.; Kuehl, S. A. The significance of large sediment supply, active tectonism, and eustasy on margin sequence development: Late Quaternary stratigraphy and evolution of the Ganges-Brahmaputra delta. Sediment. Geol. 2000, 133 (3), 227-248.

(28) McArthur, J. M.; Banerjee, D. M.; Hudson-Edwards, K. A.; Purohit, R.; Mishra, R.; Ravenscroft, P.; Cronin, A.; Howarth, R. J.; Chatterjee, A.; Talukder, T.; Lowry, D.; Houghton, S.; Chadha, D. K. Natural organic matter in sedimentary basins and its relation arsenic in anoxic groundwater: The example of West Bengal and its worldwide implications. Appl. Geochem. 2004, 19, 1255-1293.

(29) McArthur, J. M.; Ravenscroft, P.; Banerjee, D. M.; Milsom, J.; Hudson-Edwards, K. A.; Sengupta, S.; Bristow, C.; Sarkar, A.; Tonkin, S.; Purohit, R. How paleosols influence groundwater flow and arsenic pollution: a model from the Bengal Basin and its worldwide implication. Water Resour. Res. 2008, 44 (11), 1-30.

(30) Goodbred, S. L., Jr.; Kuehl, S. A. Enormous GangesBrahmaputra sediment discharge during strengthened early Holocene monsoon. Geology 2000, 28, 1083-1086.

(31) McArthur, J. M.; Nath, B.; Banerjee, D. M.; Purohit, R.; Grassineau, N. Palaeosol control on groundwater flow and pollutant distribution: the example of arsenic. Environ. Sci. Technol. 2011, 45, 1376-1383.

(32) Pickering, J. L.; Goodbred, S. L.; Reitz, M. D.; Hartzog, T. R.; Mondal, D. R; Hossain, Md.S. Late Quaternary Sedimentary Record and Holocene Channel Avulsions of the Jamuna and Old Brahmaputra River Valleys in the Upper Bengal Delta Plain. Geomorph. 2014, 227, $123-136$.

(33) Hoque, M. A.; McArthur, J. M.; Sikdar, P. K. Sources of lowarsenic groundwater in the Bengal Basin: investigating the influence of the last glacial maximum using a $115-\mathrm{km}$ traverse across Bangladesh. Hydrogeol. J. 2014, 22, 1535-1547.

(34) PHED. Public Health Engineering Department, Final Report; Steering Committee, Arsenic Investigation Project: Kolkata, India, 1991; $57 \mathrm{pp}$.

(35) van Geen, A.; Zheng, Y.; Versteeg, R.; Stute, M.; Horneman, A.; Dhar, R. K.; Steckler, R.; Gelman, M.; Small, C.; Ahsan, H.; et al. Spatial variability of arsenic in 6000 tubewells in a $25 \mathrm{~km} 2$ area of Bangladesh. Water Resour. Res. 2003, 39, 1140. 
(36) Mukherjee, A.; Fryar, A. E.; Scanlon, B. R.; Bhattacharya, P.; Bhattacharya, A. Elevated arsenic in deeper groundwater of the western Bengal Basin, India: extent and controls from regional to local scale. Appl. Geochem. 2011, 26, 600-613.

(37) McArthur, J. M.; Ghosal, U.; Sikdar, P. K.; Ball, J. D. Arsenic in groundwater: the deep late Pleistocene aquifers of the western Bengal Basin. Environ. Sci. Technol. 2016, 50, 3469-3476.

(38) Sikdar, P. K. Hydrogeology of the area in and around Calcutta and Howrah Municipal Corporation with special emphasis on the management of groundwater resources, Unpubl. Ph.D. Thesis, University of Calcutta, 1996; 163 pp.

(39) Sikdar, P. K. Geology of the Quaternary aquifers of the twin city of Calcutta-Howrah. J. Geol. Soc. India 2000, 56, 169-181.

(40) Ghosal, U.; Sikdar, P. K.; McArthur, J. M. Palaeosol control of arsenic pollution: the Bengal Basin in West Bengal, India. Groundwater 2015, 53, 588-599.

(41) Chatterjee, A.; Mukherjee, A. Hydrogeological investigation of ground water arsenic contamination in South Calcutta. Sci. Total Environ. 1999, 225, 249-262.

(42) Guha Mazumder, D. N.; Das Gupta, J.; Chakraborty, A. K.; Chatterjee, A.; Das, D.; Chakraborti, D. Environmental pollution and chronic arsenicosis in South Calcutta. Bull. World Health Org. 1992, 70 (4), 481-485.

(43) Chatterjee, A.; Das, D.; Chakraborti, D. A study of ground water contamination by arsenic in the residential area of Behala, Calcutta due to industrial pollution. Environ. Pollut. 1993, 80, 57-65.

(44) Sengupta, S.; Sarkar, A. Stable isotope evidence of dual (Arabian Sea and Bay of Bengal) vapour sources in monsoonal precipitation over north India. Earth Planet. Sci. Lett. 2006, 250, 511-521.

(45) Hoque, M. A.; McArthur, J. M.; Sikdar, P. K.; Ball, J. D.; Molla, T. N. Tracing recharge to aquifers beneath an Asian megacity with $\mathrm{Cl} /$ $\mathrm{Br}$ and stable isotopes: the example of Dhaka, Bangladesh. Hydrogeol. J. 2014, 22, 1549 .

(46) Zheng, Y.; van Geen, A.; Stute, M.; Dhar, R. K.; Mo, Z.; Cheng, Z.; Horneman, A.; Gavrieli, I.; Simpson, H. J.; Versteeg, R.; Steckler, M.; Grazioli-Venier, A.; Goodbred, S.; Shahnewaz, M.; Shamsudduha, M.; Hoque, M. A.; Ahmed, K. M. Geochemical and hydrogeological contrasts between shallow and deeper aquifers in the two villages of Araihazar, Bangladesh: implications for deeper aquifers as drinking water sources. Geochim. Cosmochim. Acta 2005, 69, 5203-5218.

(47) Stollenwerk, K. G.; Breit, G. N.; Welch, A. H.; Yount, J. C.; Whitney, J. W.; Foster, A. L.; Uddin, M. N.; Majumder, R. K.; Ahmed, $\mathrm{N}$. Arsenic attenuation by oxidized aquifer sediments in Bangladesh. Sci. Total Environ. 2007, 379, 133-150. et al. (Erratum 2008, Sci. Total Environ., 389, 567-568).

(48) van Geen, A.; Bostick, B. C.; Trang, P. T. K.; Lan, V. M.; Mai, N.-N.; Manh, P. D.; Viet, P. H.; Radloff, K.; Aziz, Z.; Mey, J. L.; Stahl, M. O.; Harvey, C. F.; Oates, P.; Weinman, B.; Stengel, S.; Frei, F.; Kipfer, R.; Berg, M. Retardation of arsenic transport through a Pleistocene aquifer. Nature 2013, 501, 204-207.

(49) McArthur, J. M. Element partitioning in ferruginous and pyritic phosphorite on the Moroccan continental margin. Mineral. Mag. 1978, 42, 221-228.

(50) Belzile, N.; Lebel, J. Capture of arsenic by pyrite in near-shore marine sediments. Chem. Geol. 1986, 54, 279-281.

(51) Moore, J. N.; Ficklin, W. H.; Johns, C. Partitioning of arsenic and metals in reducing sulfidic sediments. Environ. Sci. Technol. 1988, 22, 432-437.

(52) Rittle, K. A.; Drever, J. I.; Colberg, P. J. S. Precipitation of arsenic during bacterial sulfate reduction. Geomicrobiol. J. 1995, 13, 111.

(53) Nickson, R. T.; McArthur, J. M.; Ravenscroft, P.; Burgess, W. G.; Ahmed, K. M. Mechanism of arsenic poisoning of groundwater in Bangladesh and West Bengal. Appl. Geochem. 2000, 15, 403-413.

(54) Kresse, T. M.; Fazio, J. A. Occurrence of Arsenic in Groundwaters of Arkansas and Implications for Source and Release Mechanisms; Arkansas Dept. of Environmental Quality, Water Quality Report WQ03-03-01, Little Rock, AR, 2003.
(55) Kirk, M. F.; Holm, T. R.; Park, J.; Jin, Q.; Sanford, R. A.; Fouke, B. W.; Bethke, C. M. Bacterial sulfate reduction limits natural arsenic contamination in groundwater. Geology 2004, 32, 953-956.

(56) Appleyard, S. J.; Angeloni, J.; Watkins, R. Arsenic-rich groundwater in an urban area experiencing drought and increasing population density, Perth, Australia. Appl. Geochem. 2006, 21, 83-97.

(57) Lowers, H. A.; Breit, G. N.; Foster, A. L.; Whitney, J.; Yount, J.; Uddin, M. N.; Muneem, A. A. Arsenic incorporation into authigenic pyrite, Bengal Basin sediment, Bangladesh. Geochim. Cosmochim. Acta 2007, 71, 2699-2717.

(58) Buschmann, J.; Berg, M. Impact of sulfate reduction on the scale of arsenic contamination in groundwater of the Mekong, Bengal and Red River deltas. Appl. Geochem. 2009, 24, 1278-1286.

(59) McArthur, J. M.; Sikdar, P. K.; Hoque, M. A.; Ghosal, U. Wastewater impacts on groundwater: $\mathrm{Cl} / \mathrm{Br}$ ratios and implications for arsenic pollution of groundwater in the Bengal Basin. Sci. Total Environ. 2012, 437, 390-402.

(60) Kondakis, X. G.; Makris, N.; Leotsinidis, M.; Prinou, M.; Papapetropoulos, T. Possible health effects of high manganese concentration in drinking water. Arch. Environ. Health 1989, 44, $175-178$.

(61) Spangler, A. H.; Spangler, J. G. Groundwater manganese and infant mortality rate by county in North Carolina: An ecological analysis. Ecohealth 2009, 6, 596-600.

(62) Wasserman, G. A.; Liu, X.; Parvez, F.; Factor-Litvak, P.; Ahsan, H.; Levy, D.; Kline, J.; van Geen, A.; Mey, J.; Slavkovich, V.; Siddique, A. B.; Islam, T.; Graziano, J. H. Arsenic and manganese exposure and children's intellectual function. NeuroToxicology 2011, 32, 450-457.

(63) Bouchard, M. F.; Sauve, S.; Barbeau, B.; Legrand, M.; Brodeur, M. E.; Bouffard, T.; Limoges, E.; Bellinger, D. C.; Mergler, D. Intellectual impairment in school-age children exposed to manganese from drinking water. Environ. Health Perspect. 2010, 119, 138-143.

(64) Oulhote, Y.; Mergler, D.; Barbeau, B.; Bellinger, D. C.; Bouffard, T.; Brodeur, M. E.; Saint-Amour, D.; Legrand, M.; Sauvé, S.; Bouchard, M. F. Neurobehavioral function in school-age children exposed to manganese in drinking water. Environ. Health Perspect. 2014, 122, 1343-1350.

(65) McArthur, J. M.; Sikdar, P. K.; Nath, B.; Grassineau, N.; Marshall, J. D.; Banerjee, D. M. (2012). Sedimentological control on $\mathrm{Mn}$, and other trace elements, in groundwater of the Bengal Delta. Environ. Sci. Technol. 2012, 46, 669-676.

(66) Ying, S. C.; Schaefer, M. V.; Cock-Esteb, A.; Li, J.; Fendorf, S. 2017. Depth stratification leads to distinct zones of manganese and arsenic contaminated groundwater. Environ. Sci. Technol. 2017, 51, $8926-8932$.

(67) WHO Guidelines for Drinking Water Quality, $4^{\text {th }}$ ed.; World Health Organization: Geneva, 2017; 541 pp.

(68) WHO Guideline: Sodium Intake for Adults and Children; World Health Organization: Geneva, 2012.

(69) Khan, A. E.; Scheelbeek, P. F. D.; Shilpi, A. B.; Chan, Q.; Mojumder, S. K.; Rahman, A.; Haines, A.; Vineis, P. Salinity in drinking water and the risk of (pre)eclampsia and gestational hypertension in coastal Bangladesh: a case-control study. PLoS One 2014, 9 (9), e108715.

(70) Scheelbeek, P. F. D.; Khan, A. E.; Mojumder, S.; Elliott, P.; Vineis, P. Drinking water sodium and elevated blood pressure of healthy pregnant women in salinity-affected coastal areas. Hypertension 2016, 68 (2), 464-470.

(71) Vengosh, A.; Pankratov, I. Chloride/bromide and chloride/ fluoride ratios of domestic sewage effluents and associated contaminated ground water. Groundwater 1998, 36, 815-824.

(72) Panno, S. V.; Hackley, K. C.; Hwang, H. H.; Greenberg, S. E.; Krapac, I. G.; Landsberger, S.; O'Kelly, D. J. Characterization and identification of $\mathrm{Na}-\mathrm{Cl}$ sources in ground water. Groundwater 2006, 44, 176-187.

(73) Davis, S. N.; Whittemore, D. O.; Fabryka-Martin, J. Uses of chloride/bromide ratios in studies of potable water. Groundwater 1998, 36, 338-350. 
(74) Nissenbaum, A.; Magaritz, M. Bromine-rich groundwater in the Hula Valley, Israel. Naturwissenschaften 1991, 78, 217-218.

(75) Desbarats, A. J.; Koenig, C. E. M.; Pal, T.; Mukherjee, P. K.; Beckie, R. D. Groundwater flow dynamics and arsenic source characterization in an aquifer system of West Bengal, India. Water Resour. Res. 2014, 50, 4974-5002.

(76) Berg, M.; Trang, P. T. K.; Stengel, C.; Buschmann, J.; Viet, P. H.; Van Dan, N.; Giger, W.; Stüben, D. Hydrological and sedimentary controls leading to arsenic contamination of groundwater in the Hanoi area, Vietnam: the impact of iron-arsenic ratios, peat, river bank deposits, and excessive groundwater abstraction. Chem. Geol. 2008, 249 (1-2), 91-112.

(77) Postma, D.; Mai, N. T. H.; Lan, V. M.; Trang, P. T. K.; Sø, H. U.; Nhan, P. Q.; Larsen, F.; Viet, P. H.; Jakobsen, R. Fate of arsenic during Red River water infiltration into aquifers beneath Hanoi, Vietnam. Environ. Sci. Technol. 2017, 51 (2), 838-845.

(78) ICCIDD (2013) FAQs about iodine nutrition, International Council for the Control of Iodine Deficiency Disorders (ICCIDD). http://www.iccidd.org/p142000355.html\#p4, Cited 30 July 2013.

(79) Sahu, P.; Sikdar, P. K. Effect of pumping on hydrologic system of a young satellite city in south Bengal Basin through numerical modelling: past, present and future. Sustain. Water Resour. Manag. 2017, 3 (3), 321. 